\title{
Poor Tuberculosis Treatment Outcomes Associated with Older Age, Previous Treatment, HIV and Drug Resistance at Seven Hospitals in Indonesia
}

\author{
Dampak Buruk Pengobatan Tuberkulosis Berhubungan dengan Usia \\ Lanjut, Pengobatan Sebelumnya, HIV dan Resistensi Obat di Tujuh Rumah \\ Sakit di Indonesia
}
Dona Arlinda ${ }^{1}$, Retna Mustika Indah ${ }^{1}$, Aris Yulianto ${ }^{1}$, Agus Dwi Harso ${ }^{1}$, Armaji Kamaludi Syarief ${ }^{1}$, Muhammad Karyana $^{1}$
1) Center for Health Resources and Services Research, NIHRD, Jl. Percetakan Negara 29, Jakarta 10560, Indonesia Corresponding Author: arlindona1@gmail.com

Submitted: 13 May 2020, Revised: 22 July 2020, Accepted: 26 August 2020

https://doi.org/10.22435/jpppk.v4i2.3698

\begin{abstract}
Indonesia is a high burden country for tuberculosis (TB), multidrug-resistant (MDR) TB, and TB-HIV. We aimed to determine factors associated with poor TB treatment outcomes. A hospital-based TB Registry at seven referral hospitals in Java and Bali included data from patients aged $\geq 15$ years who were diagnosed with TB from 1 January 2014 - 31 December 2015. The factors were assessed by logistic regression. From 2,051 TB patients, 1,180 (57.5\%) were male and median age was 38 years (IQR 27-50 years), $452(22 \%)$ had previous TB treatment history, 1,447 (70.6\%) had pulmonary TB, $216(10.5 \%)$ TB-HIV, 296 (14.4\%) TB-DM and $248(12.1 \%)$ were resistant to $\geq 1$ anti-TB drug. Treatment outcome was unknown for $135(6.6 \%)$ subjects and $1,137(55.4 \%)$ who were still on treatment. Among the 779 with available outcome, $358(46 \%)$ were treatment success, $248(31.8 \%)$ transferred out, 112 (14.4\%) defaulted, $46(5.9 \%)$ died and $15(1.9 \%)$ failed. After controlling other factors, poor TB treatment was associated with age $\geq 38$ years $(p=0.003$; aOR 1.58; 95\% $\mathrm{Cl} 1.2-2.1)$, previous history of TB treatment ( $<<0.001$; aOR 2.55; $95 \% \mathrm{Cl} 1.5-4.2)$ and resistance to $\geq 1$ anti-TB drug ( $p<0.001$; aOR $11.66 ; 95 \% \mathrm{Cl} 3.8-36.1)$. Mortality was associated with previous history of TB treatment $(p=0.003$; aOR 3.87; 95\% Cl 1.7-9.6), TB-HIV ( $p=0.001$; aOR 10.43; 95\% Cl 4.2-26.1), and resistance to $\geq 1$ anti-TB drug ( $p=0.001 ;$ aOR $9.48 ; 95 \% \mathrm{Cl} 2.6-34.0)$. Treatment in TB patients with older age, history of previous TB treatment, HIV, and drug resistance should be closely monitored.
\end{abstract}

Keywords: Indonesia, tuberculosis, treatment outcome

\begin{abstract}
Abstrak
Indonesia adalah negara dengan beban tinggi untuk tuberkulosis (TB), TB resisten obat (MDR) dan TBHIV. Analisis ini bertujuan untuk menentukan faktor yang terkait dengan luaran pengobatan TB yang buruk. Registri TB berbasis rumah sakit di tujuh rumah sakit rujukan di Jawa dan Bali mencakup data dari pasien berusia $\geq 15$ tahun yang didiagnosis TB dari 1 Januari 2014 - 31 Desember 2015. Faktor-faktor tersebut dinilai dengan regresi logistik. Dari 2.051 pasien TB, 1.180 (57,5\%) laki-laki dan median usia 38 tahun (IQR 2750 tahun), 452 (22\%) memiliki riwayat pengobatan TB sebelumnya, 1.447 (70,6\%) memiliki TB paru, 216 (10,5\%) TB-HIV, 296 (14,4\%) TB-DM dan 248 (12,1\%) resisten terhadap $\geq 1$ obat anti-TB. Luaran pengobatan TB tidak diketahui untuk 135 (6,6\%) subjek dan 1.137 (55,4\%) yang masih dalam pengobatan. Di antara 779 dengan luaran pengobatan diketahui, 358 (46\%) pengobatan berhasil, 248 (31,8\%) pindah, 112 (14,4\%) putus pengobatan, 46 (5,9\%) meninggal dan 15 (1,9\%) gagal. Setelah dikontrol terhadap faktor lain, luaran pengobatan TB yang buruk dikaitkan dengan usia $\geq 38$ tahun ( $p=0,003$; aOR 1,58; $95 \%$ Cl 1,2-2,1), riwayat pengobatan TB sebelumnya ( $p<0,001$; aOR 2,55 ; $95 \%$ Cl 1,5-4,2) dan resistansi terhadap $\geq 1$ obat anti-TB ( $p$
\end{abstract}


$<0,001$; aOR 11,66; 95\% Cl 3,8-36,1). Kematian dikaitkan dengan riwayat pengobatan TB sebelumnya $(p=$ 0,003; aOR 3,87; 95\% Cl 1,7-9,6), TB-HIV ( $p=0,001$; aOR 10,43; 95\% Cl 4,2-26,1), dan resistansi terhadap $\geq 1$ anti -TB obat ( $p=0,001$; aOR 9,48; 95\% Cl 2,6-34,0). Pengobatan pada pasien TB dengan usia yang lebih tua, riwayat pengobatan TB sebelumnya, HIV dan resistansi obat harus dipantau secara ketat.

\section{Kata kunci: Indonesia, tuberkulosis, luaran pengobatan}

\section{Introduction}

Despite the declining trend in tuberculosis (TB) incidence rate between 2000 and 2018, Indonesia is considered a high-burden country for $\mathrm{TB}$, multidrug resistant (MDR) TB and TB/HIV. ${ }^{1}$ Indonesia has the second highest number of TB cases globally, with an estimated TB prevalence of $647 / 100,000$. Indonesia is also among the 27 highburden MDR-TB countries that accounted for more than $50 \%$ of estimated MDR-TB cases occurring worldwide in 2013. The prevalence of HIV among incident TB cases in Indonesia is $3.2 \%$, which is slightly under India and Cambodia. ${ }^{2}$

The percentage of patients treated successfully is a key indicator for monitoring and evaluating the effectiveness of the TB Directly Observed Therapy (DOT) program. Globally, an $85 \%$ treatment success rate is reported for the new and relapse TB cases who are treated in 2017 and the same rate is reported for Indonesia. ${ }^{1}$ The initial treatment for active TB disease requires the combination of at least three drugs for a minimum duration of six months. Incomplete treatment increases the risk of TB transmission, resistance, morbidity and mortality.

Studies have included older age, alcohol use, HIV, low body mass index, anemia and treatment delay as some of the factors associated with poor TB treatment outcomes..$^{3-6}$ Monitoring the TB treatment outcome is needed to evaluate the effectiveness of TB management and to identify potential barriers for TB control. However, this has not been well studied in Indonesia. Therefore, this analysis aimed to determine factors associated with poor treatment outcomes among TB patients at seven hospitals in Indonesia.

\section{Methods}

A hospital-based TB registry was established in 2014 at seven referral hospitals in Java and Bali. Patients aged 15 years and older who attended the hospitals as outpatients and were diagnosed with
TB (ICD-10 code A15-A19) between 1 January 2014 and 31 December 2015 were included in the registry. Data on socio demographics, clinical characteristics, treatment, and treatment outcome were abstracted from the patients' medical records. Ethical approval No. LB.02.01/5.2/KE423/2014 was obtained from the Health Research Ethics Committee of the National Institute of Health Research and Development, Ministry of Health of Indonesia.

In this analysis, we included participants whose data were collected until 12 January 2016. The baseline characteristics were grouped based on reported TB treatment history, i.e. treatment naïve (had never received TB treatment) and previously treated. Previously treated TB composed of patients who experienced relapse after receiving successful treatment, those who returned after default, and those who started receiving a re-treatment regimen after having treatment failure, as well as other patients (i.e., those who do not fit to any of the aforementioned categories, such as those who received unknown or unstandardized treatment regimens). Resistance to at least one anti-TB drug was based on Xpert MTB-Rif or drug susceptibility test results. HIV and diabetes mellitus (DM) status were based on physician's diagnosis as stated in the patients' medical records. The poor TB treatment outcome of interest was a composite of failed, lost to follow up, transferred out and mortality (allcause). Logistics regression was used to assess the determinants of the poor TB treatment outcomes. Significant factors with $p$-value $<0.20$ were included in a multivariate model. We reported the unadjusted and adjusted odds ratio (aOR) with $95 \%$ confidence intervals (CI). All the analysis was conducted with SPSS ver. 22.

\section{Results}

A total of 2,051 participants were included in this analysis (Table 1). The dominant participants were male and range of age was 25-44 years old. 
Pulmonary TB was the predominant type of TB and previously treated TB was documented in $22 \%$ of the participants. Cases of TB-HIV and TB-DM were both below $20 \%$. Acid fast bacilli (AFB) smear positive $\mathrm{TB}$ and resistance to at least one anti-TB drug were higher in the previously treated than in treatment-naïve participants.

Treatment outcome was unknown for 135 subjects $(6.6 \%)$ and 1,137 subjects $(55.4 \%)$ were still on treatment (Figure 1). Among the 779 participants with available data on treatment outcome, TB treatment success was lower in the previously treated than in treatment naïve $\mathrm{TB}$
(24.8\% vs 50.2\%) (Figure 2).

After controlling other factors, poor TB treatment was associated with age 38 years and older, history of previous TB treatment and resistance to at least one anti-TB drug (Table 2). After controlling other factors, mortality was associated with history of previous TB treatment, positive HIV), and resistance to at least one anti-TB drug (Table 3).

\section{Discussions}

Our results showed that only $46 \%$ of the TB registry participants had successful TB treatment. Older age, history of previous TB treatment, HIV

Table 1. Baseline Characteristics of the TB Registry Participants

\begin{tabular}{|c|c|c|c|c|c|c|c|}
\hline \multirow{2}{*}{ Characteristics } & & \multicolumn{2}{|c|}{ Total } & \multicolumn{2}{|c|}{ TB treatment naïve } & \multicolumn{2}{|c|}{ Previously treated TB } \\
\hline & & $\mathbf{N}$ & $\%$ & n & $\%$ & n & $\%$ \\
\hline \multirow[t]{5}{*}{ Age (years) } & $<25$ & 398 & 19,4 & 348 & 21,8 & 50 & 11,1 \\
\hline & $25-44$ & 913 & 44,5 & 705 & 44,1 & 208 & 46,0 \\
\hline & $45-64$ & 636 & 31,0 & 469 & 29,3 & 167 & 36,9 \\
\hline & $65+$ & 104 & 5,1 & 77 & 4,8 & 27 & 6,0 \\
\hline & Median (IQR) & 38 & $(27-50)$ & 36 & $(26-50)$ & 42 & $(30-52)$ \\
\hline \multirow[t]{2}{*}{ Sex } & Male & 1180 & 57,5 & 904 & 56,5 & 276 & 61,1 \\
\hline & Female & 871 & 42,5 & 695 & 43,5 & 176 & 38,9 \\
\hline \multirow[t]{3}{*}{ AFB smear } & Positive & 981 & 47,8 & 632 & 39,5 & 349 & 77,2 \\
\hline & Negative & 632 & 30,8 & 559 & 35,0 & 73 & 16,2 \\
\hline & Not available & 438 & 21,4 & 408 & 25,5 & 30 & 6,6 \\
\hline \multirow[t]{3}{*}{ Type of TB } & Pulmonary TB & 1447 & 70,6 & 1025 & 64,1 & 422 & 93,4 \\
\hline & Extra pulmonary $\mathrm{TB}$ & 580 & 28,3 & 551 & 34,5 & 29 & 6,4 \\
\hline & Mixed & 24 & 1,2 & 23 & 1,4 & 1 & 0,2 \\
\hline \multirow[t]{3}{*}{ HIV status } & TB-HIV & 216 & 10,5 & 183 & 11,4 & 33 & 7,3 \\
\hline & TB-non-HIV & 1182 & 57,6 & 868 & 54,3 & 314 & 69,5 \\
\hline & Not available & 653 & 31,8 & 548 & 34,3 & 105 & 23,2 \\
\hline \multirow[t]{3}{*}{ DM status } & TB-DM & 296 & 14,4 & 181 & 11,3 & 115 & 25,4 \\
\hline & TB-non-DM & 1679 & 81,9 & 1348 & 84,3 & 331 & 73,2 \\
\hline & Not available & 76 & 3,7 & 70 & 4,4 & 6 & 1,3 \\
\hline \multirow{3}{*}{$\begin{array}{l}\text { Resistance to at least } \\
1 \text { anti-TB drug }\end{array}$} & Resistant* & 248 & 12,1 & 23 & 1,4 & 225 & 49,8 \\
\hline & Sensitive & 391 & 19,1 & 289 & 18,1 & 102 & 22,6 \\
\hline & Not available & 1412 & 68,8 & 1287 & 80,5 & 125 & 27,7 \\
\hline Total (n, \%) & & 2051 & 100 & 1599 & 78,0 & 452 & 22,0 \\
\hline
\end{tabular}

AFB: acid fast bacilli; DM: diabetes mellitus; IQR: interquartile range

*based on either Xpert MTB-Rif or drug susceptibility test 


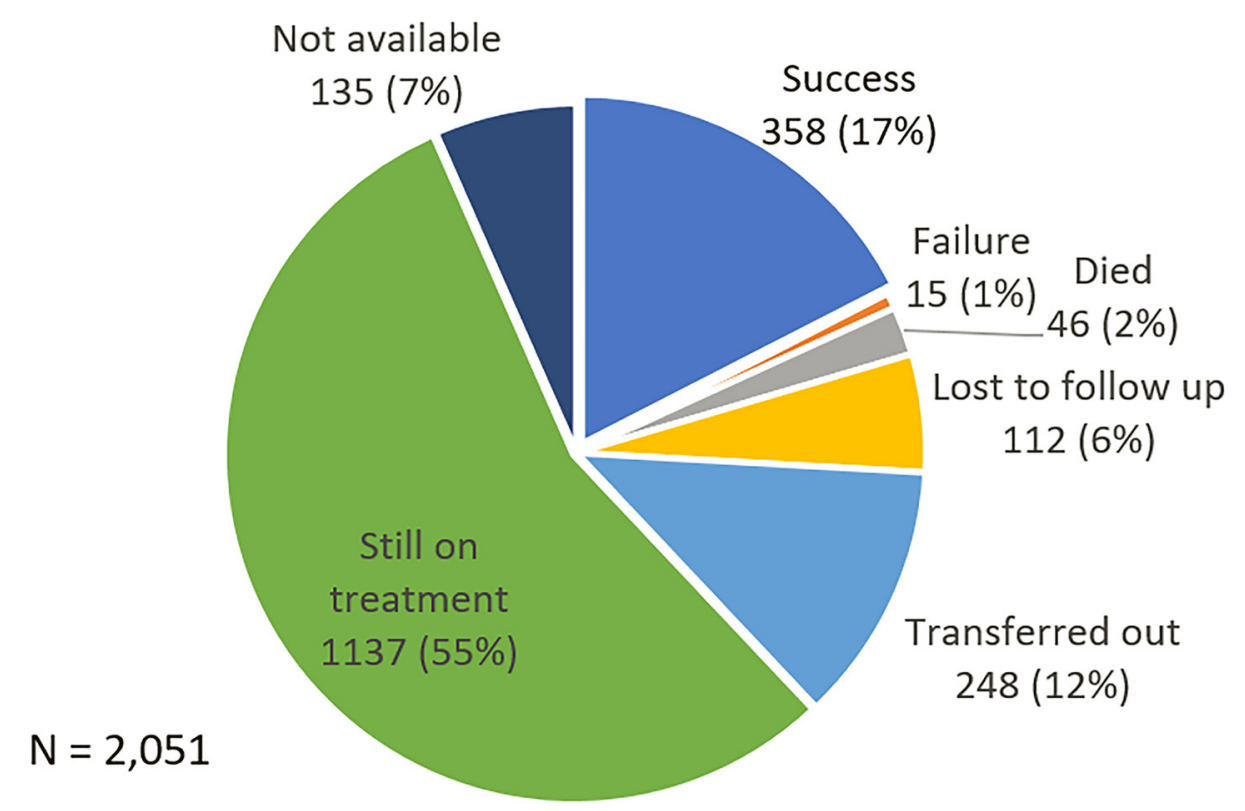

Figure 1. Overall Distribution of Treatment Course and Outcomes in the TB Registry

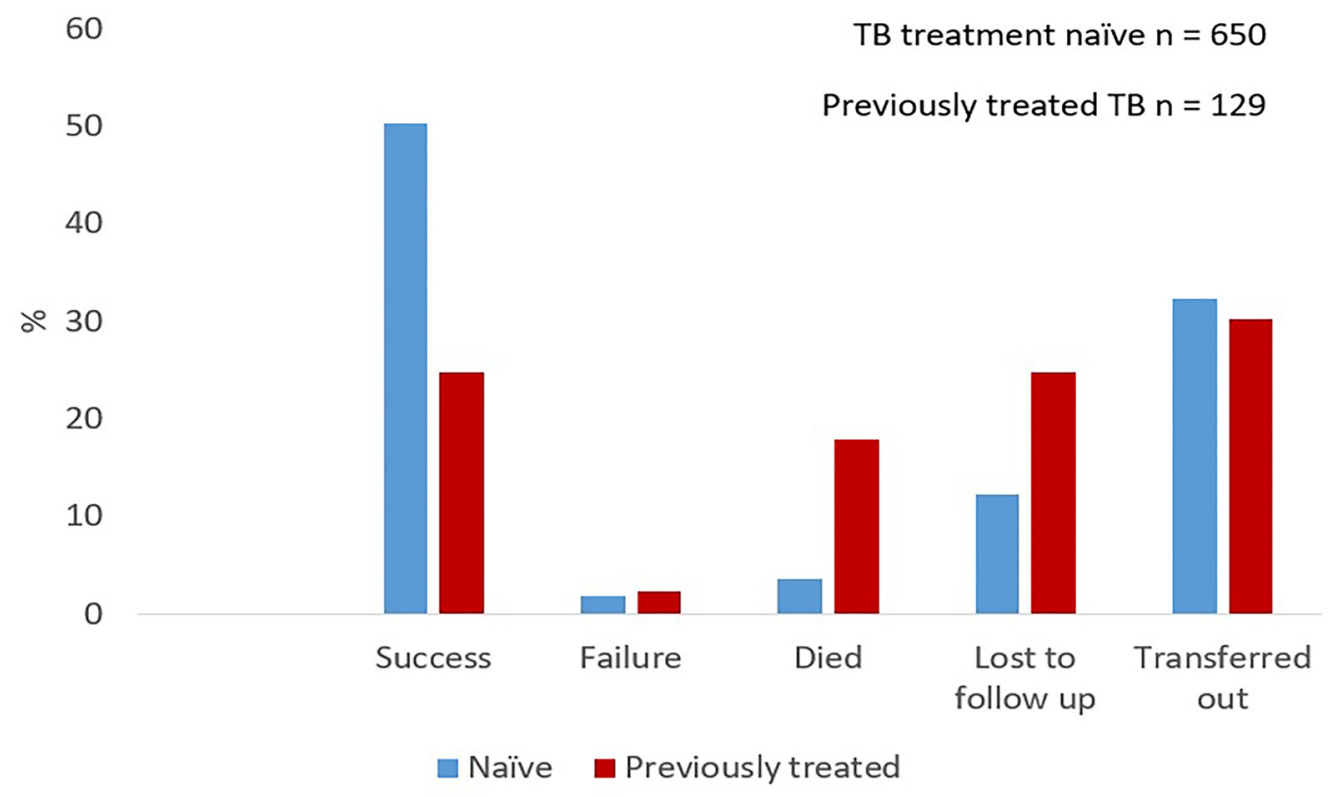

Figure 2. Distribution of Available Treatment Outcome by TB Treatment History

positive, and resistance to at least one anti-TB drug were significantly associated with poor TB treatment outcomes. The rate of TB treatment success in this study was much lower than the $85 \%$ success rate reported globally. ${ }^{1}$ And this result still lower than a study in India that reported TB treatment success rate was $72.5 \%$, while in China was $95 \%$, where both are countries with high burden of TB. ${ }^{7,8}$

Older age ( $\geq 38$ years) was significantly associated with poor TB treatment in this study and was consistent with recent studies. ${ }^{9-11}$ Previously treated TB in this study (22\%) was higher than the $11 \%$ reported in India, a country with the highest TB burden in the world. ${ }^{12}$ Older aged patients, especially those with previously treated TB, are often clinically more complicated. They are more difficult to manage and may stay infectious for a longer time. They also bear individual risks of experiencing drug resistance and poor treatment outcomes, thus became an important group for TB control and should not be neglected. ${ }^{13,14}$

This study showed a $10.5 \%$ proportion of 
TB-HIV and the odds for all-cause mortality was at least ten times higher among TB/HIV when compared to TB patients who were HIV negative. The proportion of TB/HIV among TB patients in this study was higher than that reported in India (3.1\%) and Denmark (4.6\%). ${ }^{15,16}$ To address the dual burden of TB and HIV, the WHO have advocated and emphasized the need for integrated TB and HIV services, and provided guideline on collaborative TB-HIV activities for national programs and other stakeholders. In Indonesia, the TB-HIV collaborative activities have been initiated, and enhancement of these activities is among the strategies outlined in the national strategic plan for TB control.

Table 2. Risk Factors for Poor TB Treatment

\begin{tabular}{|c|c|c|c|c|c|c|c|c|c|c|}
\hline \multirow{2}{*}{\multicolumn{2}{|c|}{ Variable }} & \multicolumn{2}{|c|}{ Total } & \multicolumn{2}{|c|}{ Not Success } & \multicolumn{2}{|c|}{ Success } & \multirow{2}{*}{ p } & \multirow{2}{*}{ OR (95\% CI) } & \multirow{2}{*}{$\operatorname{aOR}(95 \% \mathrm{CI})$} \\
\hline & & $\mathbf{n}$ & $\%$ & $\mathbf{n}$ & $\%$ & $\mathbf{n}$ & $\%$ & & & \\
\hline Age (years) & $\geq 38$ & 392 & 50,3 & 233 & 55,3 & 159 & 44,4 & 0,003 & $1,55(1,2-2,1)$ & $1,58(1,2-2,1)$ \\
\hline & $<38$ & 387 & 49,7 & 188 & 44,7 & 199 & 55,6 & & Ref. & Ref. \\
\hline Sex & Male & 444 & 57,0 & 242 & 57,5 & 202 & 56,4 & 0,624 & $1,04(0,8-1,4)$ & - \\
\hline \multirow{3}{*}{ Type of TB } & Female & 335 & 43,0 & 179 & 42,5 & 156 & 43,6 & & Ref. & \\
\hline & $\begin{array}{l}\text { Extra pulmo- } \\
\text { nary }\end{array}$ & 235 & 30,2 & 132 & 31,4 & 103 & 28,8 & 0,759 & $1,12(0,8-1,6)$ & - \\
\hline & Mixed & 8 & 1,0 & 5 & 1,2 & 3 & ,8 & 0,672 & $1,48(0,3-6,2)$ & \\
\hline \multirow{3}{*}{$\begin{array}{l}\text { TB treatment } \\
\text { history }\end{array}$} & Pulmonary & 536 & 68,8 & 284 & 67,5 & 252 & 70,4 & & Ref. & \\
\hline & $\begin{array}{l}\text { Previously } \\
\text { treated }\end{array}$ & 129 & 16,6 & 97 & 23,0 & 32 & 8,9 & $<0,001$ & $3,05(1,9-4,7)$ & $2,55(1,5-4,2)$ \\
\hline & Naive & 650 & 83,4 & 324 & 77,0 & 326 & 91,1 & & Ref. & Ref. \\
\hline \multirow[t]{2}{*}{ HIV status } & Positive & 57 & 7,3 & 29 & 6,9 & 28 & 7,8 & 0,875 & $1,03(0,6-1,8)$ & - \\
\hline & Not available & 285 & 36,6 & 173 & 41,1 & 112 & 31,3 & 0,118 & $1,54(1,1-2,1)$ & \\
\hline \multirow{3}{*}{ DM status } & Negative & 437 & 56,1 & 219 & 52,0 & 218 & 60,9 & & Ref. & \\
\hline & Positive & 66 & 8,5 & 43 & 10,2 & 23 & 6,4 & 0,295 & $1,66(0,9-2,8)$ & - \\
\hline & Not available & 17 & 2,2 & 9 & 2,1 & 8 & 2,2 & 0,293 & $0,99(0,4-2,6)$ & \\
\hline \multirow{4}{*}{$\begin{array}{l}\text { Resistance to } \\
\text { at least } 1 \text { anti- } \\
\text { TB drug }\end{array}$} & Negative & 696 & 89,3 & 369 & 87,6 & 327 & 91,3 & & Ref. & \\
\hline & Resistant & 48 & 6,2 & 44 & 10,5 & 4 & 1,1 & $<0,001$ & $22,43(7,6-65,8)$ & $11,66(3,8-36,1)$ \\
\hline & Not done & 576 & 73,9 & 326 & 77,4 & 250 & 69,8 & $<0,001$ & $2,65(1,8-3,7)$ & $3,68(2,4-5,7)$ \\
\hline & Sensitive & 155 & 19,9 & 51 & 12,1 & 104 & 29,1 & & Ref. & Ref. \\
\hline
\end{tabular}

aOR: adjusted odds ratio

Drug resistance TB is a significant barrier to effective TB care and prevention which often resulted from unsupervised and inappropriate treatment, and could be seen as programmatic problem. The treatment of drug-resistant TB is complicated and inappropriate management can have life-threatening results. This study showed resistance to at least one anti-TB drug was associated with eleven times higher odds for poor treatment outcome when compared to those without resistance, with only four out of the 44 resistant participants had successful treatment. The proportion of poor TB treatment outcomes among those with resistance to at least one TB drug in this study (92\%) was much higher than that reported in India (55\%). ${ }^{17}$ This results must be responded with appropriate care to address drug resistance among TB patients and to limit further spread.

The major strength of our study is the data from major TB referral hospitals in Java and Bali. In this study, we showed which factors were associated with treatment outcome. This study results could help clinician and TB national program in managing TB patients.

Due to the timing of data extraction, more than half of TB patients were still on treatment. However, we still have a large number 
Table 2. Risk Factors for Mortality among TB Patients

\begin{tabular}{|c|c|c|c|c|c|c|c|c|c|c|}
\hline \multirow{2}{*}{\multicolumn{2}{|c|}{ Variable }} & \multicolumn{2}{|c|}{ Total } & \multicolumn{2}{|c|}{ Not Success } & \multicolumn{2}{|c|}{ Success } & \multirow[b]{2}{*}{$P$} & \multirow{2}{*}{ OR (95\% CI) } & \multirow{2}{*}{$\operatorname{aOR}(95 \% \mathrm{CI})$} \\
\hline & & n & $\%$ & $\mathbf{n}$ & $\%$ & n & $\%$ & & & \\
\hline \multirow[t]{2}{*}{$\overline{\text { Age (years) }}$} & $\geq 38$ & 392 & 50,3 & 26 & 56,5 & 366 & 49,9 & 0,386 & $1,30(0,7-2,4)$ & \\
\hline & $<38$ & 387 & 49,7 & 20 & 43,5 & 367 & 50,1 & & Ref. & \\
\hline \multirow[t]{2}{*}{ Sex } & Male & 444 & 57,0 & 31 & 67,4 & 413 & 56,3 & 0,142 & $1,60(0,8-3,0)$ & $1,26(0,6-2,6)$ \\
\hline & Femal & 335 & 43,0 & 15 & 32,6 & 320 & 43,7 & & Ref. & $\mathrm{Re}$ \\
\hline \multirow[t]{2}{*}{ Type of TB } & $\begin{array}{l}\text { Extra pulmo- } \\
\text { nary }\end{array}$ & 235 & 30,2 & 8 & 17,4 & 227 & 31,0 & 0,052 & $0,46(0,2-1,0)$ & $0,67(0,2-2,5)$ \\
\hline & Mixed & 8 & 1,0 & 0 & 0 & 8 & 1,1 & 0,999 & 0 & 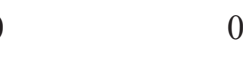 \\
\hline \multirow{3}{*}{$\begin{array}{l}\mathrm{TB} \text { treatment } \\
\text { history }\end{array}$} & Pulmonary & 536 & 68,8 & 38 & 82,6 & 498 & 67,9 & & Ref. & $\mathrm{Re}$ \\
\hline & $\begin{array}{l}\text { Previously } \\
\text { treated }\end{array}$ & 129 & 16,6 & 23 & 50,0 & 106 & 14,5 & 0,003 & $5,91(3,2-10,9)$ & $3,87(1,7-9,6)$ \\
\hline & Naïve & 650 & 83,4 & 23 & 50,0 & 627 & 85,5 & & Ref. & Ref. \\
\hline \multirow[t]{2}{*}{ HIV status } & Positive & 57 & 7,3 & 14 & 30,4 & 43 & 5,9 & $<0,001$ & $5,86(2,8-12,2)$ & $10,43(4,2-26,1)$ \\
\hline & Not available & 285 & 36,6 & 9 & 19,6 & 276 & 37,7 & 0,651 & $0,59(0,3-1,3)$ & \\
\hline \multirow{3}{*}{ DM status } & Negative & 437 & 56,1 & 23 & 50,0 & 414 & 56,5 & & Ref. & Ref. \\
\hline & Positive & 66 & 8,5 & 10 & 21,7 & 56 & 7,6 & 0,847 & $3,59(1,7-7,7)$ & \\
\hline & Not available & 17 & 2,2 & 3 & 6,5 & 14 & 1,9 & 0,254 & $4,3(1,2-15,7)$ & \\
\hline \multirow{4}{*}{$\begin{array}{l}\text { Resistance to } \\
\text { at least } 1 \text { anti- } \\
\text { TB drug }\end{array}$} & Negative & 696 & 89,3 & 33 & 71,7 & 663 & 90,5 & & Ref. & \\
\hline & Resistant & 48 & 6,2 & 17 & 37,0 & 31 & 4,2 & 0,001 & $22,43(7,6-65,8)$ & $9,48(2,6-34,0)$ \\
\hline & Not done & 576 & 73,9 & 25 & 54,3 & 551 & 75,2 & 0,060 & $2,66(1,8-3,7)$ & $2,99(0,9-9,4)$ \\
\hline & & 155 & 19,9 & 4 & 8,7 & 151 & 20,6 & & Ref. & Ref. \\
\hline
\end{tabular}

aOR: adjusted odds ratio

of TB patients for the analysis. Despite the lack of treatment adherence, which is an important factor associated with treatment outcome ${ }^{18}$, we believe with the effect size reported in our study. Adding other potential confounders will not make the results changed drastically into not significant or changed the direction of the effect (risk factor into protective factors or vice versa).

This study has some important implications. First, there is a need for more focused attention on the more vulnerable older population, which presents with worse treatment outcomes than other age groups. A reasonable step would be to systematically screen for potential comorbidities among TB patients, such as DM, which are more common in aging populations. Second, there is a need for an earlier community HIV testing and treatment among TB patients to prevent late presentation of HIV with severe disease. Third, there is also a need for earlier testing for drug resistance among TB patients, including among newly diagnosed TB to identify transmitted resistance.

\section{Conclusion}

To avoid poor treatment among TB patients in Indonesia, special attention should be given to patients with older age, history of previous TB treatment, HIV and drug resistance. Close monitoring should be given specifically to these patients to ensure they stay on treatment. More effort should be made to identify drug resistance and HIV among TB patients.

\section{Author Contributions}

DA wrote first draft of the paper and prepared the references. DA and RMI processed and analyzed the data. AY, ADH, AKS retrieved and managed the data. MK supervised data management and analysis. All authors read and approved the final manuscript. 


\section{Acknowledgements}

Hospital director, research team and the patients from RSUP Persahabatan, RSPI Dr. Sulianti Saroso, RSUP Dr. Hasan Sadikin, RSUP Dr. Kariadi, RSUP Dr. Sardjito, RSUD Dr. Soetomo, RSUP Sanglah.

\section{Reference}

1. Saxena A, Horby P, Amuasi J, Aagaard N, Kohler J, Gooshki ES, et al. Ethics preparedness: facilitating ethics review during outbreaks - recommendations from an expert panel.. BMC Med Ethics. 2019;20(1):29. doi:10.1186/ s12910-019-0366-x

2. Trinh QM, Nguyen HL, Nguyen VN, Nguyen TV, Sintchenko V, Marais BJ. Tuberculosis and HIV co-infection-focus on the AsiaPacific region. Int $J$ Infect Dis. 2015;32:170-8. doi:10.1016/j.ijid.2014.11.023

3. Alemu A, Bitew ZW, Worku T. Poor treatment outcome and its predictors among drugresistant tuberculosis patients in Ethiopia: A systematic review and meta-analysis. Int $J$ Infect Dis. 2020;98:420-439. doi:10.1016/j. ijid.2020.05.087

4. Harausz EP, Garcia-Prats AJ, Law S, Schaaf HS, Kredo T, Seddon JA, et al. Treatment and outcomes in children with multidrug-resistant tuberculosis: A systematic review and individual patient data meta-analysis. PLoS medicine. 2018;15(7):e1002591. doi:10.1371/journal. pmed.1002591

5. Harris RC, Grandjean L, Martin LJ, Miller AJ, Nkang JE, Allen V, et al. The effect of early versus late treatment initiation after diagnosis on the outcomes of patients treated for multidrugresistant tuberculosis: a systematic review. $B M C$ Infect Dis. 2016;16:193. doi:10.1186/s12879016-1524-0

6. Ragan EJ, Kleinman MB, Sweigart B, Gnatienko N, Parry CD, Horsburgh CR, et al. The impact of alcohol use on tuberculosis treatment outcomes: a systematic review and metaanalysis. Int J Tuberc Lung Dis. 2020;24(1):7382. doi:10.5588/ijtld. 19.0080

7. Singh A, Prasad R, Kushwaha RAS, Srivastava $\mathrm{R}$, Giridhar $\mathrm{BH}$, Balasubramanian $\mathrm{V}$, et al. Treatment outcome of multidrug-resistant tuberculosis with modified DOTS-plus strategy: A 2 years' experience. Lung India. 2019;36(5):384-92. doi:10.4103/lungindia. lungindia_475_18

8. Wen Y, Zhang Z, Li X, Xia D, Ma J, Dong Y, et al. Treatment outcomes and factors affecting unsuccessful outcome among new pulmonary smear positive and negative tuberculosis patients in Anqing, China: a retrospective study. BMC Infect Dis. 2018;18(1):104. doi:10.1186/ s12879-018-3019-7

9. Tok PSK, Liew SM, Wong LP, Razali A, Loganathan T, Chinna K, et al. Determinants of unsuccessful treatment outcomes and mortality among tuberculosis patients in Malaysia: A registry-based cohort study. PLoS One. 2020;15(4):e0231986. doi:10.1371/journal. pone. 0231986

10. Nanzaluka FH, Chibuye S, Kasapo CC, Langa $\mathrm{N}$, Nyimbili S, Moonga G, et al. Factors associated with unfavourable tuberculosis treatment outcomes in Lusaka, Zambia, 2015: a secondary analysis of routine surveillance data. The Pan African medical journal. 2019;32:159. doi:10.11604/pamj.2019.32.159.18472

11. Melese A, Zeleke B. Factors associated with poor treatment outcome of tuberculosis in Debre Tabor, northwest Ethiopia. BMC Res Notes. 2018;11(1):25. doi:10.1186/s13104-018-3129-8

12. Shewade HD, Gupta V, Satyanarayana S, Kharate A, Murali L, Deshpande M, et al. Are we missing 'previously treated' smear-positive pulmonary tuberculosis under programme settings in India? A cross-sectional study. F1000Res. 2019;8:338. doi:10.12688/f1000research.18353.2

13. Rifat M, Hall J, Oldmeadow C, Husain A, Hinderaker SG, Milton AH. Factors related to previous tuberculosis treatment of patients with multidrug-resistant tuberculosis in Bangladesh. BMJ Open. 2015;5(9):e008273. doi:10.1136/ bmjopen-2015-008273

14. Mohd ShariffN, Shah SA, Kamaludin F. Previous treatment, sputum-smear nonconversion, and suburban living: The risk factors of multidrugresistant tuberculosis among Malaysians. Int $J$ Mycobacteriol. 2016;5(1):51-8. doi:10.1016/j. ijmyco.2015.11.001

15. Holden IK, Lillebaek T, Seersholm N, Andersen 
PH, Wejse C, Johansen IS. Predictors for Pulmonary Tuberculosis Treatment Outcome in Denmark 2009-2014. Sci Rep. 2019;9(1):12995. doi:10.1038/s41598-019-49439-9

16. Singanayagam A, Manalan K, Connell DW, Chalmers JD, Sridhar S, Ritchie AI, et al. Evaluation of serum inflammatory biomarkers as predictors of treatment outcome in pulmonary tuberculosis. Int $J$ Tuberc Lung Dis. 2016;20(12):1653-60. doi:10.5588/ ijtld.16.0159

17. Takhar RP, Saxena A, Khangarot S, Garg R,
Bansiwal B, Shringi KN. Treatment outcome of multi-drug resistant tuberculosis (MDR-TB) patients at a tertiary care center of Northern India. European Respiratory Journal. 2019;54. doi:10.1183/13993003.congress-2019.PA4639

18. Alipanah N, Jarlsberg L, Miller C, Linh NN, Falzon D, Jaramillo E, et al. Adherence interventions and outcomes of tuberculosis treatment: A systematic review and metaanalysis of trials and observational studies. PLOSMedicine.2018;15(7):e1002595. doi:10.1371/journal.pmed.1002595 